\title{
Beyond "Seclusionist" Japan: Evaluating the Free Afghans/R efugee Law Reform Campaign after September 11
}

\author{
Mai Kaneko
}

\begin{abstract}
Following the events of September 11, Japan renewed its stance against terrorism and aggressively stepped up regulations against aliens including asylum seekers. Responding to the post-September 11 detention of Afghan asylum seekers, citizens of all walks of life joined forces. The Free Afghan Refugees movement not only succeeded in releasing detainees, but also broke new ground by pushing for reform of the Japanese asylum system for the first time in the twenty-one years since the Refugee Recognition Act was enacted. The success and propagation of their activism is a reflection of the maturity attained by the refugee rights movement in Japan, and the increased awareness among citizens about world issues. On an unprecedented scale, citizens are questioning the government's efforts to maintain a homogeneous social order.
\end{abstract}

\section{Résumé}

À la suite des attentats du 11 septembre, le Japon a réitéré sa position contre le terrorisme et a vigoureusement renforcé ses règlements contre les étrangers, y compris les demandeurs d'asile. Cependant, lorsque des demandeurs d'asile afghans ont été détenus après le 11 septembre, des citoyens provenant de toutes les couches sociales ont fait cause commune. Le mouvement «Libérez les réfugiés afghans » ( «Free Afghan Refugees») réussit non seulement à obtenir la libération des détenus, mais innova aussi en réclamant la réforme du système d'asile japonais pour la première fois depuis les 21 années d'existence de la Loi sur la reconnaissance des réfugiés ( «Refugee Recognition Act »). Le succès et la propagation du militantisme attestent du degré de maturité atteint par le mouvement pour les droits des réfugiés au Japon et de la sensibilisation accrue des citoyens envers les grandes questions mondiales. Comme jamais auparavant, les citoyens remettent en question les efforts du gouvernement pour préserver un ordre social homogène.

Ever since I was a kid, I'd always imagined that Japan was the most peaceful country in the world ... I was taught that after the H iroshima bombing, Japanese people came to love peace. Ever since I was born I've seen nothing but war. I grew up seeing people being killed right in front of me.... ${ }^{1}$

I thought if I came to Japan, I would be safe and would be able to makea future for myself. But instead, as soon asI arrived here I was detained and treated likea criminal.... All we think about is our family. We don't know where they are, how they are ... whether they are alive or dead... All we can do while in detention is to keep watching the horrible news on TV about the US bombing our hometown ... We just hope and pray nothing has happened to them. (Afghan detainee, Hazara, male, in his twenties). ${ }^{2}$

Right after September 11th, I found out that one of my acquaintances was killed in the World Trade Center. I thought some thing was wrong with this world and started to becomeinvolved in social activism for the first time in my life. That is how I came to know about detained Afghan asylum seekers. Until then, I was just an "ordinary citizen." When I heard the term "refugees," I just imagined thesepeoplestarving in therefugeecamps in Asia and Africa. They are part of something happening far away from me. I would never havethought that thereare people 
who come to Japan seeking "asylum." ... But look at me now, I'm in the middle of the Free Afghan refugee movement ... Why? Because I came to realize that my life, which I take for granted, exists at the expense of these people... A society not livable for refugees is not livable for us Japanese, either. (Japanese businessman, in his thirties). ${ }^{3}$

Thefirst comment wasmade by an Afghan asylum seeker who was detained by the Japanese immigration bureau for seven months, and the second comment was made by a young Japanese activist who became involved in the move ment to free them after September 11. While the plight of detainees languishing in places like Woomera, Australia, has made international headlines since 2001, neither the trauma that theseA fghan asylum seekers faced in J apan nor the support they garnered from citizens has been widely recognized. In the early morning hours of O ctober 3, 2001, soon after September 11 and the Bush administration's declaration on war against terrorism, some forty Japanese police and I mmigration Bureau officials armed with bulletproof vests raided the residences of nine Afghan asylum seekers in Chiba, and transported them to the immigration detention facility in Jujo, Tokyo. The police and immigration officials allegedly confiscated computers and cell phones from the residents, and even examined their personal diaries. These asylum seekers, most of them minority H azaras, ${ }^{4}$ were allegedly arrested under suspicion of terrorism, and were detained under poor medical conditions with no prospect of release, and many of them attempted to commit suicide. This provoked widespread criticism among Japanese citizens, and many lawyers, Christian activists, journalists, and young activists became mobilized to found the N etwork to Free Afghan Refugees (AFNET). ${ }^{5}$

What is most remarkable about this movement is that a considerable number ${ }^{6}$ of young and mainstream citizens were involved, many participating in such activism for the first time in their lives. At the same time, their movement, which started out as a campaign against the detention of Afghan asylum seekers, has not only succeeded in securing the release of a number of detainees, but has also evolved into a whole new effort to push for the reformation of the Japanese asylum system itself. The revised Immigration Control and Refugee Recognition Bill, ${ }^{7}$ - though with many problems - ostensibly advocating the prevention of detention and deportation of asylum seekers is now about to be submitted by the Cabinet to the Diet, the Japanese parliament. Japan, a country that has long practised exclusionary immigration and asylum policy in maintaining its self-proclaimed status as a "homogeneous society," is finally facing major pressure for change by its citizens claimingthat only "asocietylivablefor foreignersislivable for all."

In this paper, I will first discuss the pre-September 11 policy on detention of asylum seekers, and how regulations against aliens including asylum seekers were gradually tightened in recent years, followed by theimpact of September 11 given the new agenda of countering terrorism, the success of Free Afghans and asylum system reform movement, and finally analyze what factors contributed to the dramatic propagation of the movement after September 11.

\section{Japanese Seclusionist Policy}

Japan ratified the Convention Relating to the Status of Refugees (hereinafter Refugee Convention) ${ }^{8}$ and its Protocol ${ }^{9}$ in 1981, and enacted the Immigration Control and Refugee Recognition Act (hereinafter Immigration Act) ${ }^{10}$ shortly afterward. Japan, home country to former United N ations High Commissioner for Refugees (UN H CR) Sadako Ogata, is the second-largest donor to the UNHCR following the U.S., with many of its nationals all over the world devoted to international cooperation on such issues as refugee assistance. However, asylum seekers in Japan have faced severe circumstances. Between 1981 and the end of 2002, twentyoneyearssinceratification of the RefugeeC onvention, Japan has only recognized 305 out of a total of 2,782 applicants. In 2001, the year the nine Afghans mentioned above were detained, 353 people applied for refugee status - the highest in nineteen years - with only twenty-six recognized. M ost applicants for refugee status were Afghans - almost one hundred - yet only three were recognized. ${ }^{11}$ The number of refugees J apan admits every year has been the lowest among all G7 countries. Further, in comparing the numbers of refugees hosted to a number of other variables, Japan is ranked $136^{\text {th }}$ internationally in relation to GDP, $125^{\text {th }}$ in relation to population size, and $90^{\text {th }}$ in relation to geographic size, at the end of 2000.12 At the same time, even before September 11, refugee advocates have long claimed that the Japanese asylum system itself contains considerable flaws with potentials of serious human rights violations such as detentions of asylum seekers without a timelimit and deportations to home countries where there is fear of persecution.

\section{Pre-September 11: Detention of Asylum Seekers}

Under Japan's I mmigration Act, any alien who arrives without proper documentation, including those who subsequently seek asylum, must be detained. Amnesty International reported in 2002 that a daily average of seven persons are detained at the Landing Prevention Facilities (LPFs) (or "Airport Rest House") in Narita Airport alone. ${ }^{13}$ On the other hand, since the Japanese government does not provide any particular visa to refugee applicants, in-country 
applicants without valid documents at the time of application also face detention and deportation. (Those who do have visas at the time of application for refugee status may have their visas extended during this initial application, but not during appeal. These individuals therefore face detention and deportation). In contrast, in the years before September 11, those without visas at the time of application normally had deportation procedures suspended and were therefore not detained until their initial application was denied. ${ }^{14}$

Once in the immigration detention facilities, detainees may request provisional release to the immigration bureau in exchange for bail provided that there is "no possibility of the detainees' running away," and in light of such factors as detainees' health. However, before September 11, provisional release was usually granted only when the applicant had been detained for several months or close to a year.

These practices have garnered criticisms by the U NHCR, refugee advocates, and lawyers as contradictory to international law and standards, including the Refugee Convention Article 33 (non-refoulement); Article 31, which exempts refugees from punishment due to illegal entry or presence; UNHCR Detention Guidelines, ${ }^{15}$ which stipulate that detention of refugees be neither automatic nor unduly prolonged; and UNHCR Executive Committee Conclusion $44,{ }^{16}$ which states that detention of asylum seekers "should normally be avoided." Reflecting these criticisms, the de tention of asylum seekers had been decreasing from 1999 to 2000 until the wake of September 11 when the Japanese authority joined the international campaign against terrorism advocated by the Bush administration - in which immigration and national security becameinextricably linked. According to the UNHCR, in 2001, the year nine Afghans were detained, the percentage of asylum seekers detained in Japan reached levelsconsi derably higher than those of other industrialized nations, with the exception of Australia. ${ }^{17}$ Tokyo Lawyers League for Afghan Refugees, a Japanese lawyers group established after September 11, reported that in February 2002, at least fifty asylum seekers were detained in immigration bureau facilities in Tokyo, I baraki, O saka, and other areas. $^{18}$

\section{Pre-September 11: Aliens as Security Issues}

Actually, even before September 11 Japanese authorities, specifically thel mmigration Bureau and thepolice, had been tightening regulations against aliens in an effort to prevent "international organized crimes" that threaten domestic security. Especially since the late 1990s, the police have played a significant role in Japan's immigration control policy by arresting aliens for violations of immigration law. Refugee and migrant advocates claim that reason for this is the deep-rooted idea that Japanese social order is based on the homogeneity of Japanese society. For example, in 1997, when Chinese smuggling was a big issue, many government officials expressed concern about the "threats posed by illegal migrants and smugglers to the social order." The Chief of the Investigation Bureau of the National Police Association, on theincreasing number of aliens, asserted that "Japanese society ... is completely unprepared for these people."19 While the police had been claiming that undocumented aliens "were responsible for the increasing number of felonious crimes committed by foreigners," there is no valid ground for this claim. The events of September 11 in this sense did not suddenly change Japanese immigration policy. Rather, they strengthened the al ready close relationship between the police and immigration authorities via the new common agenda of countering terrorism. ${ }^{20}$ At the same time, in November 2001, the immigration control act was revised, which enabled the government to deny entry to those who "may disturb international conferences or sports tournaments (such as soccer hooligans)" at the port of the entry, and to deport those who committed certain crimes once considered minor. Behind this reform lies an ongoing attempt by the Japanese government to share information about terrorists with other governments.

\section{Post September 11: Detention of Afghan Asylum Seekers}

It was then in this context that on October 3,2001, the Japanese police and Immigration Bureau officials in cooperation raided the nine Afghan asylum seekers and detained them in Jujo, Tokyo. Those who were arrested had not even had their initial application denied, in contradiction to the detention practices in previous years. While they were primarily arrested for violation of immigration laws, it is clear that they were suspected of being connected with the Taliban, the fundamentalist Islamic army led by Mohammad Omar, or al Qaeda, the international Islamic army led by Osama bin Laden. In fact, on September 17, prior to the detention of the nine Afghans, the Immigration Bureau requested that Afghan refugee applicants, including several of the nine individuals, appear at the Tokyo Immigration Bureau. Bureau staff interrogated the refugee applicants, asking them whether they were related to Taliban members or knew anything about 0 sama bin Laden. ${ }^{21}$ Shortly after the arrest of thenineAfghans, a ministerial meeting on anti-terrorism measures ${ }^{22}$ was held. It was decided that it was vital to arrest "illegal aliens who may be related to terrorist organizations." H owever, the JusticeM inistry failed to provide any evidence of the aliens' relationship with any terrorist organizations, and instead began claiming that the nine Afghans were actually economic refugees or migrant work- 
ers pretending to be refugees. ${ }^{23}$ Ironically, not only were the arrested Afghans uninvolved with any terrorist organizations, but they were actually from the main group of people persecuted by the Taliban regime. This incident itself shows a lack of awareness on the part of the Immigration Bureau concerning the situation in Afghanistan. The Immigration Bureau, in interviews with the ethnically $\mathrm{H}$ araza Afghan asylum seekers, allegedly employed Pashtun and Tadzhik interpreters. In Afghanistan, these ethnic groups have historically been antagonistic against $\mathrm{H}$ azaras, putting the asylum seekers at a tremendous disadvantage.

Hearing the extraordinary news of the arbitrary detention of asylum seekers still in the process of initial application, a group of refugees and migrants rights lawyers founded the Tokyo Lawyers League for Afghan Refugees (hereinafter Lawyers League), and claimed the illegality, according to international law and standards, of the Afghans' detention. However, by the end of November, all nine were denied refugee status, and were eventually sent to the immigration detention center in U shiku, Ibaraki. ${ }^{24}$

\section{Birth of AFNET and Release of D etainees}

After the five asylum seekers were detained in Ushiku, the Lawyers League discovered a total of twenty-three Afghan asylum seekers detained in the same facility, most of them minority $\mathrm{H}$ azaras in their late teens and twenties. $\mathrm{M}$ any had arrived in the summer and fall of 2001, and were detained at the airport while filing their application for refugee status. They were subsequently sent to Ushiku and detained for months. Until discovered by the Lawyers League, most were without contact with the outside world, and had not been notified of their right to legal representation. The Lawyers Leagueimmediately filed suits to nullify or cancel the deportation order that had been issued to them, as well as made requests for provisional release to the Immigration Bureau. However, the Immigration Bureau responded that given the instability of Afghanistan, deportation was not possible, and declared that the detainees remain in detention until it became possible to deport them.

On the other hand, almost all the detained Afghan asylum seekers suffered from post-traumatic stress disorder (PTSD), because of the persecution they experienced in Afghanistan. PTSD patients, when put in situations similar to those in which the initial traumas occurred, suffer from symptoms such as flashbacks and headaches. Detention in a small cell, which many of the detainees have experienced while being persecuted by the Taliban, reawakened their traumatic experiences. Due to uncertainty about their futures because of indefinite detention and worries about their families, by M arch 2002, a total of fourteen asylum seekers had attempted to commit suicide by overdosing on sl eeping drugs, attempted hanging, and burning themselves. ${ }^{25}$

Everyday, wearelosing our minds.... The Taliban kill usin one moment, but here, we are being killed day by day, little by little. We do not know when we can get out. Back in Afghanistan I never thought of killing myself - I thought it was such a stupid idea ... you know why? Because you're going be killed anyway. But after I experienced the Japanese detention center, I understand now so well why someone would want to end his life.

(Afghan asylum seeker, H azara, male, in his twenties). ${ }^{26}$

Detainees were only allowed to bathe and exercise three times a week (less than onehour each time) in the detention center; ${ }^{27}$ as a result, detainees suffered from scabies and different deceases. D octors stationed at the detention center were often inaccessible, ${ }^{28}$ and the medical care provided was problematic; ${ }^{29}$ when the detainees asked for medicine, the doctor allegedly did not limit the quantity, with the result that detainees took excessive amount of sleeping pills. Detainees needed advance permission to see outside doctors, and some detainees later said that they were handcuffed on the way to the doctor. Some detainees claimed that they were verbally abused by detention officers, who allegedly demanded that the detainees address them as "sensei" (in Japanese, "teacher") and made such statements as, "Why did you come to Japan? Go back to your own country." 30 $M$ any demonstrated their dissatisfaction by hunger strikes and self-mutilation.

In response to this situation, on December 25, the $\mathrm{N}$ etwork to Support Afghan Refugees (AFNET), a network of citizens consisting of organizations such as the Lawyers League, Solidarity N etwork with Migrants Japan (SMJ), Christian Coalition for Refugees and Migrant Workers (CCRM W), the newly founded youth group Chance!, and individuals such as journalists, was established.

M embers of AFNET lobbied Diet members, held forums and press conferences, visited detainees periodically, conducted a letter-writing campaign to detainees as well as the Justice $\mathrm{M}$ inister, and conducted rallies. A petition to free the detainees was circulated; more than 5,400 signatures were gathered from all over Japan. The network, in collaboration with Christian and lawyers' groups in Osaka which had been supporting many Afghan asylum seekers, was strengthened and enabled AFNET to conduct its national campaign.

In responseto AFN ET lobbying, groups of Diet members visited and investigated the $U$ shiku detention center, as well as criticized the immigration authority in the Diet. On February 21, 2002, UNHCR published a press release condemning the detention, stating “. ... it is U N HCR's view that 
the detainees should be released under alternative arrangement until their return becomes possible in safety. UN HCR believes that their prolonged detention only adds to the suffering of these people." 31 In addition, major newspapers in Japan reported on the plight of Afghans languishing in detention. ${ }^{32}$

On March 1, 2002, the Tokyo district court made the historical decision to suspend the deportation order, as a result releasing seven Afghan detainees and recognizing them as refugees. ${ }^{33}$ The court decision stated that the detainees were recognized as "refugees ... with well-founded fear of persecution, and should be provided appropriate protection." Detention, the court continued, would "only further give them immeasurable pains." By April 26, less than two months after the decision, all twenty-three Afghan detainees gained provisional release from the U shiku detention center. According to the Lawyers League, in 2000 the Immigration Bureau detained 2,214 aliens, and only nine detainees gained provisional release, which is only 0.4 per cent. This figure demonstrates how extraordinary the release was.

On the other hand, AFNET and other supporters faced a new challenge. The Japanese government did not provide residency status, accommodations, or medical care to the former detainees. Christian organizations such as the Catholic Commission of Japan for M igrants, Refugees and People on the Move (J-CARM), and CCRM W therefore collected donations from churches and citizens, and through the Japan Association for Refugees (JAR) provided the released Afghans with shelter (most of it owned by churches) and funds to cover living expenses. JAR in cooperation with such organization as International Social Services Japan (ISSJ) provided everyday assistance. It is important to notethat though very small and not politically organized, ${ }^{34}$ there is a community of A fghans settled in the Chiba area, which has eased the former detainees' adaptation to Japanese society. Some of the Afghans who themselves had gained residency as refugees put tremendous effort into acting as liaisons between the detainees and lawyers and NGO workers before and after the refugees' release.

At the same time AFNET, despite concerns about the possible negative effects of the media presence, ${ }^{35}$ on the whole encouraged former detainees to express themselves through television, newspapers, and magazines. In terms of public advocacy this led to fairly positive outcome. For example, a series of television Asahi programs in which a nineteen-year-old Afghan attending a local Japanese junior high school expressed his desire to stay in Japan in order to keep studying attracted much sympathy from mainstream citizens, who had a limited and sometimes biased image about the people of Afghanistan. Also, it can be said that this heightened public attention worked to prevent there-detention of seven Afghansin J uly 2002. ${ }^{36}$

\section{Shengyang Incident and the D evelopment of the Law Reform Movement}

In M ay 2002, the government of Japan was at the center of an international controversy. Chinese police officers force fully prevented a North Korean family (which included a two-year-old child) from seeking asylum at the compound of the Japaneseconsulatein Shengyang, China. The Japanese government desperately argued that China violated the 1963 Vienna Convention on Consular Relations. ${ }^{37}$ However, it was later revealed that the apanese consulate officials themselves did not resist the police, and even went as far to indirectly assist them. It is clear that, by assisting the police, these officials were being complicit in China's violation of thenon-refoulement principle. Beforethe incident, the thenJapanese ambassador to China allegedly told the consulate officials to kick out any "suspicious persons" coming into the compound, an act representative of Japan's extreme resistance toward asylum. ${ }^{38}$

The incident sparked widespread criticism against Japan's policy on asylum, and the AFNET-led "free Afghan detainees movement" therefore evolved into a movement to review Japan's asylum law. In June2002, the N etwork for Refugee Law R eform-Japan (REFNET) ${ }^{39}$ was established by the citizens involved in AFNET with a broader goal of revising asylum law and policies in Japan. REFNET held a series of forums on refugee law reform for both citizens and Diet members, as well as conducted lobbying efforts. REFNET published a booklet titled "Beyond Seclusionist Japan" targeted to a wide range of people which comprehensively addressed the problems and suggested alternatives to the current refugee policy. ${ }^{40}$

In response to the public criticism, on June 11, 2002, the M inistry of Justice established a Special Working Group on Refugee Issues ${ }^{41}$ under the Justice M inister's Private Council on Immigration Control Policy. Justice M inister Moriyama, in her opening address at the Council on June 11, stated that "given the drastic change in world order, globalization, and rising public awareness on refugee issues, it is crucial for our Ministry to review ... and improve our refugee recognition system." On N ovember 1 , the working group published a progress report on their review of the refugee recognition system, ${ }^{42}$ which stated that the various amendments proposed in the report are "messages to indicate to the international society that Japan will be more positive in accepting refugees from now on." 43 The progress report made a remarkable proposal on the issue of detention and deportation of asylum seekers. The report pro- 
posed to provide a provisional legal status to refugee applicants, until their appeal is turned down so that those without valid documents will not be deported and detained for their illegal stay. As of February 2003, the bill is about to be approved in the Cabinet and submitted to theDiet. Though there is certainly some room for criticism of the bill, such as the strict conditions it requires for obtaining provisional legal status, discussion of such criticisms is outside the scope of my paper (see note 43). What is important here is that the M inistry of J ustice seems to be finally changing its attitude, if only slowly.

\section{Historical Analysis of the Post-September 11 Movement}

I have so far provided an overview of citizens' activism in Japan for refugee rights in the aftermath of September 11. I would now like to explore why this movement has been so successful and what contributed to the propagation of movement beyond generation. In order to do this, I would like to bri efly trace the evolution of the refugee rights movement in the past twenty years. First of all, it should be noted that though there are many Japanese humanitarian and development N GO sengaged in ai ding and assisting refugees abroad, organizations concerned with refugees within Japan are comparatively few.

With theend of theV ietnam War in 1975, so-called "boat people" started to arrive in Japan, and the Japanese government, responding to pressure from foreign governments, decided to admit the Indo-Chinese refugees for resettlement exceptionally on an annual quota basis through a cabinet understanding (about 10,600 were admitted from 1979 to 2000). In Japan these Indo-Chinese refugees are clearly distinguished from those who go through the official refugee recognition procedure based on the Refugee Convention which Japan ratified in 1981 . Their resettlement procedure, though difficult, is considered to be fairly successful. The extensive media coverage of the Vietnam War led to a heightened awareness of the condition of these refugees, as did a strong anti-war movement in Japan. It is possible that since many Japanese citizens still had a direct memory of W orld War II, this too contributed to a generally sympathetic attitude toward the refugees.

These Indo-Chinese refugees were provided full social services by the government such as accommodation, education, health, and job training by government, and many citizens' groups and non-governmental organizations supported them. Specifically, the role played by Catholic churches and organizations was remarkable. ${ }^{44}$ As early as 1975, in response to a UN request, Caritas Japan, a relief agency of the Catholic Church, started to provide temporary shelters for Vietnamese refugees rescued from the sea, and since 1979, in cooperation with governmental organizations, has provided land for resettlement assistance centres for the refugees. In 1982, the Catholic Bishops' Conference of Japan set up the Special N ational Committee for the Settlement of Refugees (renamed the Committee for the Settlement of Refugees), and each diocese began to providehelp for the refugees within its territory. This Committee was later absorbed into the Japan Catholic Commission for International Cooperation (renamed the Commission of Japan for M igrants, Refugees and Peopleon the Move), which played an important role in assisting Afghan refugees after September 11. In addition, it has been noted that many Catholics were involved in refugee assistance on an individual basis, such as language education and mental care. ${ }^{45}$

After the surge of Indo-Chinese refugees was settled, the Committee for International Cooperation Archdiocese of Osaka established a Refugee H elp D esk in 1993. Theorganization originally assisted convention refugees such as those from Sudan and Ethiopia, and started to support Afghan refugees in 1999; ${ }^{46}$ their experience contributed to the birth of AFNET. This involvement of Catholic churches and Catholics in the protection of refugees can be understood in the context of Christian egalitarianism, as well as their worldwide endeavour to assist refugees and migrants since the Pope declared solidarity with these individuals. At the same time, it is important to note that there were quite a few Catholics among the refugees ( 30 to 35 per cent in the case of the Vietnamese refugees) coming into Japan. ${ }^{47}$ M eanwhile, Protestant churches have been less organized in terms of commitments to refugee issues. Even the Christian Coalition for Refugees and Migrant Workers (CCRM W), established in 1989 as Japan's national interdenominational network of Christians including Protestants and Catholics concerned with refugees and migrant rights, only began itsfocus on refugees after September 11, when they became involved in the activities of AFNET and REFNET.

Turning to non-Christian groups, Amnesty International's Japanese Section founded the "Refugee Team" as early as 1992, which not only acted in concert with Al's global campaign in support of refugees, but also engaged in advocacy activities directed at J apanese refugee policy. The team also assisted asylum seekers in the representation of their cases by providing reports on the human rights situation in each country; however, their "no-work-on-owncountry" principle has prevented the organization as a whole from taking action on individual cases. It should be noted that although the Refugee Recognition Act was enacted in 1982, the number of people applying for refugee status as well as those recognized remained very small until 1995. It was 1996 when the number of refugee applicants 
went up dramatically; it doubled from 52 in 1995 to 147 in $1996 .{ }^{48}$ This led to an increased number of asylum seekers who pursued lawsuits after their appeals were rejected, and the lawyers who became involved in defending asylum seekers' rights, many of them working pro bono, established the Japan Lawyers N etwork for Refugees (JLNR) in 1997. In 1999, given the fact that unlike the Indo-Chinese refugees there were hardly any social services available for those who went through refugee recognition procedure whether recognized or denied, the Japan Association for Refugees (JAR) was established; JAR is the first NGO which specializes in assisting individual asylum seekers and refugees in Japan by providing legal and social services. By 2000, the Working Group on Refugee Assistance in Japan (RAJA), which includes JLNR and JAR, was established within PAR in AC Japan, a partnership network between UNHCR and Japanese NGOs working on refugees.

In response to the spread of support, some remarkable changes started to appear on the administration side: the J ustice $M$ inistry has been granting an increasing number of asylum seekers since 1998 (it jumped from one person in the previous four years to fifteen in 1998). In addition, in recent years, there have been revolutionary court cases in which asylum seekers as plaintiffs have won the cases. The pre-September 11 movement to support refugees had been coming to a rapid maturation, and represents an important context in which the birth of AFNET and REFNET after September 11 must be seen. The post-September 11 detention of Afghan asylum seekers provided an emotionally charged and publicly visible issue which critically stimulated the refugee rights movement on a national level. The mobilization after September 11 has cut across professional, denominational, and generational lines. It is important to note that REFNET was established as Japan's first NGO led by ordinary citizens, whose primary goal is the reform of Japan's asylum policies and system.

In addition to the missi on of refugee law reform, another important REFNET goal has been, through a number of unique projects, to raise public awareness on refugee issues, particularly focusing on those who identify themselves as "ordinary citizens." In addition to distributing colourful and catchy flyers on refugee issues, REFNET has been engaged in such activities as dispatching asylum seekers and lawyers or activists to local schools to educate students about refugee issues within Japan. With donations collected by REFNET, the first Afghan restaurant in Kanda, Tokyo, which is run by refugees themselves, was opened in February 2003. REFNET is planning several events in which Japanese citizens and asylum seekers and refugees, not only from Afghanistan but also from all over theworld, can meet and become acquainted with each other (as one can easily imagine, for many of the Japanese participants, it may be their first time to see people from certain countries). What is remarkable about these projects is that they are being spearheaded by young activists, many of whom are participating in social activism for the first time in their lives.

Below, I would like to closely look at why these relatively young activists, who until recently have been rarely seen in the ranks of migrants and refugee rights activists, have become involved in the Free Afghans and Refugee Law Reform Campaign after September 11.

\section{AFNET, REFNET and Young Activists}

(Before I camehere) I felt impatient about the fact that I was not doing anything to help peopleseeking help right here(in Japan). I'm tired of living as if I'm not seeing anything, dragged by a huge power, being sad .... U sually, I don't talk about serious stuff (i.e., politics and human rights etc.), but here, I feel comfortable talking about them. To be honest, I didn't know anything about what's going on, but nobody made fun of me or anything for that. I feel relieved because there'reso many young peoplelikeme! (Female, in her twenties, after participating in a refugee rights meeting). ${ }^{49}$

Since the beginning of the Free Afghans Movement, the young members of such groups as Chance! $!^{50}$ and Peace Boat, ${ }^{51}$ many of them in their teen and twenties, have deeply involved themselves in collective AFNET and REFNET activities, as well as engaging in their own unique activism as a separate group. Chance!, a citizens' group made up of "ordinary citizens," became mobilized immediately after September 11, largely via mass e-mailing, and conducted a series of peace walks (a total of five thousand participated in the seventeen walks they conducted). The first peace walks bore anti-war themes but some of the later ones focused on the effort to free Afghan asylum seekers. Chance! had a peak of two thousand members on their mailing list, where messages on a range of activist issues were exchanged. Many students and young artists, such as singers, painters, designers, and comedians, became involved in the Free Afghans movement, and some conducted street performances on behalf of Afghan detainees. They put their various talents to use in an effort to raise public awareness on the issue. As a comment on the plight of detainees, some built and entered a plastic cage talking to passersby. Some composed songs on detainees. $M$ any of these young activists state their belief that Japanese youth today tend to be apolitical and indifferent to social problems happening around them. To address this concern, Chance!'s slogan, prominently displayed on their website, is "Change our Indifference into Awareness!." 
The media played a critical role in these young people becoming mobilized in support of refugee rights after September 11 . Following the attacks, television and radio stations, newspapers and magazines began publishing and broadcasting the World Trade Center tragedy on a daily basis, as well as the U.S. attack on Afghanistan and its devastation. Attorney Ohashi, one of the leading lawyers devoting himself to pro bono work at the Lawyers League on behalf of Afghan refugees, states:

One of the reasons why today'sJapanese society is not 'refugee friendly' is because most Japanese citizens have such limited knowledge about what is going on in the world ... about the poverty, ethnic conflict, war, internally displaced persons and refugees, and the unfair world structure that produces these issues. Thistime, because of the hugemedia coverage presenting the tragedy of Afghanistan over and over, a situation that is pretty extraordinary for Japanese society emerged ... Boom! suddenly, everybody knew of the perilous situation in Afghanistan, and where this group of asylum seekers were coming from. ${ }^{52}$

This can further be explained by the comments of some of the young members of a newly founded group called "RAFIQ" (in Dari, Afghan Persian, "friends"), which works on behalf of refugees in the 0 saka area. In October 2002, the founders of RAFIQ conducted a hunger strike demanding that the Immigration Bureau release detained asylum seekers. Twenty people participated. One of the leading members, a twenty-one-year-old, wrote to other refugee supporters about his changing awareness of social issues through his involvement in the refugee rights movement:

Ithas only been two dayssincel started thestrike, but it'sal ready getting tough. Today I went into a supermarket to get some water, and was surprised: There is so much food here! I just didn't realize how wealthy Japan was ... I imagined children starving in Afghanistan, thinking how hard it must be to be starving to death ... (J apanese, male, twenty-one). ${ }^{53}$

Although thecomment may appear naïve, it remains important to the extent that it reflects a change, though small, that is occurring in Japan. It may be argued that the events of September 11 brought many "indifferent" citizens in Japan to realize the unfairness of much of the global political structure, as well as the fact that they are indirectly responsible for what is happening in the world. $M$ any have come to realize that the luxuries they enjoy, which they take for granted, has come at the expense of those in the South and even refugees within their own country and at the expense of those excluded under the governmental efforts to maintain a homogeneous social order.

\section{Conclusion}

Following the events of September 11, the government of Japan stepped up regulations against aliens, including asylum seekers, with a renewed agenda to counter terrorism. Thechange becamemost visiblein theform of collaboration between the police and the immigration authorities. The post-September 11 detention of Afghan asylum seekers was an emotionally charged and publicly visible issue that provided an impetus for the refugee rights movement to take shape on a national level, mobilizing a wide range of people, the young and the old, who identify themselves as "mainstream citizens." Their protest against detention of Afghan asylum seekers has not only succeeded in rel easing detainees, but also promoted reform of the asylum system. The Shengyang incident further fuelled this activism, culminating in the revised refugee recognition bill that would potentially prevent unfair detention and deportation of asylum seekers. The bill is expected be submitted to the Diet during the current session. The post-September 11 propagation of the refugee rights movement has as its backdrop the rapid maturation of the movement preceding the terrorist attacks in New York. The events of September 11 and extensive media coverage on the plight of Afghanistan stirred many citizens in Japan to realize the inequities in the global political structureand the contradictions found in a society where aliens, including asylum seekers, are marginalized under the government's efforts to maintain a homogeneous social order.

At the same time, there is concern that, while Afghan detainees have attracted much public and media attention, other groups such as Burmese and Kurdish from Turkey, who make up of the largest percentage of total refugee applicants in Japan, have not received as much public attention as the Afghans. In that light, it is REFNET's job to encompass the issues of rights of asylum seekers of all nationalities, and shed light on their conditions. Also, throughout AFNET's and REFNET's activities, there has been little attem $\mathrm{t}^{54}$ to share experiences with refugee rights groups and campaigns in other countries. In my view, given the industrialized governments' increasing security concerns and attempts to link "counterterrorism measures" with immigration on a global level, it is crucial for REFNET to cooperate with movements abroad.

Lastly, I would like to quote a message from Sadako Ogata, the former UNHCR, published in one of the forums on refugee law reform in N ovember 2002, which harshly criticized the current Japanese asylum policy:

... (The small number of refugees accepted every year) leads to thequestion if Japan has really understood and tried to practice the spirit and the values embodied in the Refugee Convention. One of the reasons for Japan's asylum policy being like this 
(exclusionary) may be because of our prejudice and discrimination (against foreigners) based on the pure-ethnic group myth. However, there is no way that we can hold on to the illusion in today's globalized era. We need to overcome our insular spirit and xenophobia, and become able to relate to various problems in the world as our problems, not somebody else's. ${ }^{55}$

\section{Notes}

1. Follow-up interview with theformer detainee, Tokyo, December 31, 2002.

2. Letter by an Afghan detainee, addressed to the Christian Coalition for Refugees and M igrant W orkers, February 2002.

3. Telephone interview with Bunjiro Hara, February 24, 2003.

4. Since 1996, when the Taliban took control of Mazar-e-Sharif and more than the half of the northwest part of Afghanistan, the $\mathrm{H}$ azara people, who areShi'iteM uslims, weremadetargets of planned massacre. It is said that during the massacre in August 1998 by the Taliban in Mazar-e-Sharif, some five thousand to eight thousand $\mathrm{H}$ azaras werekilled. M assivenumbers of $\mathrm{H}$ azarashaveescaped from their homelands and turned into refugees. Even today, the situation in Afghanistan is far from stable, and there still remains the possibility of these asylum seekers being persecuted. Sayed Askar M ousavi, The $\mathrm{H}$ azaras of Afghanistan: A H istorical, Cultural, Economic and Political Study (New York: St. M artin's Press, 1997).

5. Network to Free Afghan Refugees (hereinafter AFNET); in Japanese, Zainichi Afghanistan N anmin Shien N etwork (established in 2001).

6. Since both AFNET and REFNET are made up of several organizations that themselves have their members (and their membership is sometimes fluid), it is difficult to estimate exactly how many young people belong to AFNET or REFNET.

7. See "Application Time Limit for Asylum M ay Be Scrapped," The Japan Times, 27 February 2003; online: <http://www.japantimes.co.jp/cgi-bin/getarticle.pl5?nn20030227b6.htm> (date accessed: February 25, 2003).

8. United Nations Convention Relating to the Status of Refugees (hereinafter Refugee Convention), 28July 1951, 189 U.N.T.S. 150 (entered into force 22 April 1954).

9. Protocol Relating to the Status of Refugees, 606 U.N.T.S. 267 (entered into force 4 October 1967).

10. Immigration Control and Refugee Recognition Act, Cabinet Order N 0. 319 of 1951. Latest Amendment: Law No. 135 of 2001; online: Ministry of Justice Homepage <http://www.moj.go.jp/ ENGLISH/IB/ib-19.html> (English; date accessed: February 25, 2003).

11. "Asylum CasesFiled with theM inistry of Justice Japan" (translation based on theM inistry of Justice, "H eisei 14 nen ni okeru nanminninteishasu to nitsuite," 7 February 2003), online: <http://www.ref-net.org/statistics.html> (date accessed: February 25,2003$)$. During 2001, Japan allowed sixty-seven rejected asylum applicants to remain in the country with zairyu-tokubetsu kyoka (special permission for residence), based on humanitarian concerns, including civil war in their home countries. However, this permission does not firmly guarantee the extension, and there may be a gap between the treatment of those who hold special permission for residence and those who are formally recognized as refugees under the Refugee Recognition Act.

12. United Nations High Commissioner for Refugees (hereinafter UNHCR), "Selected Indicators M easuring Capacity and Contributions of Host Countries" (April 2002), online: <http://www.unhcr.ch> (date accessed: February 25, 2003).

13. Amnesty International, "W el come to Japan?," M ay 17, 2002, online: <http://web.amnesty.org/ai.nsf/Index/asa220022002? open\&Of=C OUNTR IES\%C2\%A5JAPAN > (date accessed: February 25, 2003).

14. U.S. Committee for Refugees, "W orld Refugee Survey 2002 Country Report: Japan," online: <http://www.refugees. org/world/countryrpt/easia_pacific/jap an.ht m/> (date accessed: February 25, 2003); Lawyers Committee for H uman Rights, "Country by Country Review of Detention Procedures and Practices: Japan," September 18, 2002, online: <http:// www.Ichr.org/refugees/reports/cntry_rev_02/Japan.pdf> (date accessed: February 25, 2003).

15. UNHCR Revised Guidelines on A pplicableCriteria and Standards Relating to the Detention of Asylum Seekers, February 1999, online: fs2 http://www.unhcr.ch (date accessed: February 25,2003$)$.

16. UNHCR Executive Committee Conclusion on Detention of Refugees and Asylum Seekers, N 0. 44 (1986). Report of the $37^{\text {th }}$ Session: UN doc./A/AC.96.688.

17. UNHCR Japan, "Asylum in Japan," (May 2002), online: $<$ <ttp://www.unhcr.or.jp/protect/hogo_japan.html> (Japanese; (date accessed: February 25, 2003).

18. Kensuke Onuki and Kanae Doi, "Nanmin no Kyoseishuyo to Kyoseisokan," in Nanmin Sakoku N ihon o Kaeyo! (Beyond the Seclusionist Japan), ed. Preparation Committee, N etwork for Refugee Law Reform-Japan (REFNET), (Gendaijinbun-sha, 2002). See also "Number of Asylum Seekers Detained in Japan" (the figure is as of M ay 2002), online: <http://www.refnet.org/numbers_detained.html> (date accessed: February 25, 2003)).

19. Richard H. Friman, "Immigrants, Smuggling, and Threats to Social Order In Japan," ed. David Kyle and Rey Koslowski (Baltimore: Johns Hopkins U niversity Press, 2001), 304. Japan, which claimsitself as homogeneous, has long had minority Koreans and Chinese due to colonial history. In addition migrants (many of them undocumented) from all over the world started to flow into the country since the 1980s, due to rapid economic growth. At the end of 2001, the number of registered foreigners was $1,778,462$, which made up 1.4 per cent of the total population; by nationality, Koreans made up 632,405 , and Chinese 38,1225. An estimate of the number of undocumented migrants was 224,067. Ministry of Justice, "Gaikokujin torokusha tokei ni tsuite," June 11, 2002, "H onpo ni okeru huho zanryusha su ni tsuite," January 1, 2002, online: 
$<$ http://www.moj.go.jp/> (Japanese; date accessed: February 25, 2003).

20. Furuya Mamoru, "Nyukokukanri, Chian, Yujitaisei" (Immigration Control, Social Order and Emergency Countermeasure), M igrants' Net, October 2002, 3.

21. Asahi Shinbun, October 10, 2001.

22. "Ministerial meeting on anti-terrorism measures" is the author's translation of Kokunai terror Taisaku to ni Kansuru Kankeishocho Kaigi based on the Cabinet.

23. At the same time, in order to secure protection for refugees under the Refugee Convention, it is sometime inevitable even for NGO s to emphasize the difference between "political refugees" and "economic refugees (migrants)." However, some members of REFNET, especially those long involved in undocumented migrants' rights, have been concerned that the excessive use of the term "economic refugees" (and the negative connotation associated with it) might discourage even the newcomers to the refugee rights movement from working for migrants' rights. Although these two movements should be conducted in separate frameworks, the distinction between a "migrant" and a "refugee" is sometimes a slippery slope as one can be pushed out of her country for both political and economic reasons.

24. The Lawyers League filed lawsuits to suspend the detention of nine Afghans, and on November 6, Tokyo District Court released five of the nine Afghans (the other four belonged to another section of the court), and harshly criticized the Japanese government's asylum policy. However, by the end of N ovember, all nine were denied refugee status. On December 19, the Tokyo High Court overturned the District Court's decision, and finally the temporarily released five were re-detained at theimmigration detention center in U shiku, I baraki. Case Number: Tokyo District Court, H 13 (2001) (gyo-ku) N o.114, No.115, No.116, N o.121, N o.123. See "Five Free Afghans Detained Again," The Japan Times, 22 December 2001.

25. Although no Afghan has lost his life in the detention centres, to date two Afghan asylum seekers have committed suicide outsidethecentres. Onetook his lifein Aichi Prefecturein M ay 2002 from fear of having his application rejected and therefore being re-detained. The other, who had been waiting for five years to be recognized as a refugee, killed himself in August 2002, several months after having found out that his family had been killed by American bombs. Television programsand newspapers reported the deaths of these young Afghan men. See Takuya Asakura, "Reluctance to Accept Refugees Draws Fire," The Japan Times, 29 November 2002, online: $<$ <ttp://www.japantimes.co.jp/cgi-bin/getarticle.pl5?nn200 21129c3.htm> (date accessed: February 25, 2003).

26. Conversation with an Afghan detainee, Ushiku Immigration Detention Center, I baraki, February 22, 2002.

27. Inquiry to the Ushiku Detention Center by Attorney Kanae Doi, February 25, 2003.

28. Councillor Mizuho Fukushima, Inquiry to the Chief of the Immigration Bureau at the Committee on Judicial Affairs, the H ouse of Councillors, M arch 19, 2002.
29. Representative Munenori U eda, Inquiry to the Chief of the Immigration Bureau at the Committee on Judicial Affairs, the H ouse of Representatives, February 27, 2002.

30. Nankiren N ewsletter, M ay 15, 2002, 5.

31. UNHCR Press Release, February 21, 2002, online: <http:// www.unhcr.or.jp/news/press/pr020221_2.html> (date accessed: February 25, 2003).

32. Takuya Asakura, "Detained Afghans Languishing," TheJapan Times, 22 February 2002, online: <http://www.japantimes. co.jp/cgi-bin/getarticle.pl5?nn20020222b1.htm> (date accessed: February 25, 2003).

33. Tokyo District Court, H 13 (2001) (gyo-ku)N o.1-4, N o.166, No.170, N 0.187.

34. Because of the small population and their shaky residency status, it is hard for refugee / migrant communities in Japan to politically organizethemselves. On theother hand, thereare about two hundred Japanese initiated N GO s concerned with migrants and refugees in Japan; this contrasts with many industrial ized countries where immigrant groups take the initiative in forming such organizations. See A pichai Shipper, "Foreign Workers, NGOs, and Local Governments in Japan" (paper prepared for the Annual M eeting of the Association of Asian Studies, March 11, 2000).

35. There is al ways a risk that accompanies disclosure of one's face and name as an asylum seeker; the information may reach as far as her/his home country, thus escalating the risk of persecution upon deportation. The government where asylum is being sought might also concludethat s/hedoes not fear such persecution and reject his/her asylum application.

36. On June 11, 2002, the Tokyo High Court overturned the district court decision of $M$ arch 1 , and asa result thepreviously released seven faced re-detention. But in the end, the Immigration Bureau granted provisional releaseto theseven on July 1 , a few hours after they appeared at the Tokyo Immigration Bureau No. 2 Office.

37. Vienna Convention on Consular Relations (1963) 21 U.S.T. 77, T.I.A.S. N o.6820, 596U U.N.T.S. 261 (signed at Vienna on April 24, 1963; entered into force on M arch 19, 1967).

38. The family was later granted asylum in South Korea. Since it is impossible to go to South Korea directly from N orth Korea, there are many persons who flee to China in order to seek asylum at foreign consulates and embassies stationed there. Whiletherearean estimated 50,000 to 250,000 North Koreans entering China every year, the Chinese government, because of its concern about risking its friendship with N orth Korea, does not recognize them as refugees; instead the Chinese government often sends them back as illegal economic migrants. See Jonathan Watts, "China and US at Odds over Embassy's Korean Refugees," The Guardian, 15 M ay 2002, online: <http://www.guardian.co.uk/international/story/ 0,3604,71552 6,00. html> (date accessed: February 25, 2003).

39. Network for Refugee Law Reform-Japan (Nanmin ukeireno arikata o kangaeru nettowaaku), online: <www.refnet.org/english.html>. 
40. N etwork for Refugee Law Reform-Japan (REFNET) Preparation Committee, Nanmin Sakoku N ihon o Kaeyo! (Beyond the Seclusionist Japan), (gendaijinbun-sha, 2002).

41. Special Working Group on Refugee Issues, Justice Minister's Private Council on Immigration Control Policy (this is the author's translation of Nanmin mondai ni kansuru senmon bukai and Shutsunyukoku kanri seisaku kondankai ).

42. Special Working Group on Refugee Issues, "Nanmin nintei seido ni kansuru kento kekka (chukan-hokoku)" (progress report on their review of the refugee recognition system), N ovember 1, 2002.

43. At the same time, the progress report repeatedly claimed the necessity of countermeasures against "camouflaged refugees" abusing the asylum system, with the intent of reaping economic benefits. In fact, theconditions of obtaining provisional legal status are problematic; they exclude, for example, those who arrived in Japan via a "safethird country" and those who apply for refugeestatusmorethan six monthsafter their arrival in Japan. Another amendment in the new bill is abolition of (or extension of) the "sixty-day-rule." Thecurrent "sixty-dayrule" stipulates that requests for asylum must be filed within sixty days after arriving Japan (or sixty days after the need for protection arose), unless there have been "unavoidable circumstances" preventing timely application. The rule has been criticized by refugee advocates for "preventing refugees who might be unfamiliar with the Japanese system from obtaining refugee status, solely for the reason of not meeting the deadline." On the other hand, the bill does not address the need to create a new agency or agencies independent from the Immigration Bureau with the authority of examining initial refugee applications and/or appeals (on behalf of refugees, inde pendently from the Immigration Bureau). Such a proposal, actively promoted by REFNET and other refugee rights organizations, was deemed untimely. (Currently the initial application as well as the appeal process for refugee status is administered entirely by the Immigration Bureau, which prevents impartial and objective recognition process.)

44. Christians and churches have been a leading force in the human rights movement, especially on behalf ofmigrants and refugees in Japan. According to the research conducted by Solidarity Network with Migrants Japan (hereinafter SMJ, previously called NNSM W) in 2000, among fifty-seven organizations on behalf of refugees and migrant workers, nineteen ( 33 per cent) were church-based organizations (which is quitelarge considering that in 2000 only 1 per cent of the total population in Japan was Christian, according to the Agency for Cultural Affairs). Nanako Inaba, et al., "NGOs and Empowerment of M igrant Workers in Japan," Studies in Communication Bulletin of the Faculty of Humanities, Ibaraki University, N o.10 (September 2001), 96. See also "Social Action of the Catholic Church," Catholic Bishop's Conference of Japan W ebsite, online: <http://www.cbcj.catholic.jp/eng/ehistory/jphis.htm\#5> (date accessed: February 25, 2003).

45. M akoto Endo, Nanmin nole( "Refugee Resettlement Assistant Center") (Tokyo: Kodan-sha, 1990), 98-107; Japan Catholic
Commission for International Cooperation (Section of Resettlement of Refugees), N anmin to Tomoni (Together with Refugees), 2001.

46. Atsuko De Viscardo, "Afuganisutan nanmin no jitsujo to shien" ("Supporting Afghan Refugees"), N ankiren N ewsletter, September 2001, 5.

47. Hong Kim Linh, "Zainichi Vietnam Catholic Shinto ni T suite" (on Catholic Vietnamese in Japan), in Nanmin to Tomoni, ed. Japan Catholic Commission for International Cooperation (Section of Resettlement of Refugees), (2001), 55.

48. "Asylum CasesFiled with the M inistry of Justice Japan" (translation based on the M inistry of J ustice, "H eisei 14 nen ni okeru nanminninteishasu to nitsuite," February 7, 2003), REFNET Website, online: fs2 ttp://www.ref-net.org/statistics.html> (date accessed: February 25, 2003).

49. Anonymous, Japanese Female (translation by the author), RAFIQ W ebsite, online: <http://www.itrek.jp/ rafiq/> (Japanese/ Last U pdated: February 27, 2003).

50. The group name "Chance !" is based on John Lennon's song "All we are saying is give peace a chance...."

51. Peace Boat is an international NGO which organizes educational peace voyages on a large passenger ship every year. Young members of Peace Boat visited and organized a rally for Afghan detainees and recently founded their own working group on refugees in Japan.

52. E-M ail interview with Attorney Takeshi O hashi, February 20, 2003.

53. Takatsugu Aoki, "H ansuto-nikki (TAKA's Hunger-Strike Diary. Translation by the author)," October 13, 2002.

54. Still, REFNET member SMJ, which has been pioneering the effort to encourage NGOs to seek solidarity with migrants rights' movement overseas, has moved to establish global collaborative ties by attending international conferences such as the Regional Workshop on Democracy and Security for the Peoples of the Asian Region and making presentations on the tightening of regulation on migrantsand refugees in post-September 11 Japan.

55. Sadako O gata, "H irakareta shiya ga motomerareru higo seisaku kaikaku" (Asylum Policy Reform: What Is Needed Is More Liberal Perspective; translation by the author), (M essage for Japan Federation of Bar Associations (JFBA), November 16, 2002).

M ai Kaneko worked for the Christian Coalition for Refugees and M igrant Workers (CCRM W, Nankiren) in Japan and currently is enrolled in the School of International and Public Affairs (SIPA), Columbia University. 